\title{
Innovating Capital of a Region as an Indicator of Innovation Development: Concept, Structure, Locus
}

\author{
Merzlikina G.S. \\ Department of Management and Finance of Production Systems \\ Volgograd State Technical University \\ Volgograd, Russia \\ e-mail: merzlikina@vstu.ru
}

\begin{abstract}
This article reveals that most of the indicators used to assess the results of innovation activities (special indexes) are based on structured groups of standard indicators of innovation activity (groups of indicators combining innovation factors, activities of firms and innovation results: EU, Russia), or a special index based on four groups of indicators (human capital, economic dynamics, productivity, employment, and welfare) with several indicators in each group (the USA). It is found that none of the systems, groups of indicators or indexes in essence measure the efficacy of development, but reflects only the results of monitoring the innovation activities. In this article we suggest using the indicator of innovating capital of a region as an indicator of efficacy of a region's development, which is the value advanced into certain innovation-oriented resources of the region, which allow for the development and implementation of innovations. The structure of region's innovating capital is determined, including human, intellectual, digital capital taking part in the innovation process in the region and patent capital. The place (locus) of innovating capital in the regional capital is determined. Innovating capital has to take its certain place in the regional capital combining both material and intangible resources and human resources, and judging by this very indicator one can say that a region possesses innovating capital and augments it.
\end{abstract}

Keywords - innovation activities, regional economy, innovating capital, locus.

\section{INTRODUCTION}

Innovation development in all countries demands the attention and efforts on the part of the state to provide for the innovation attractiveness and the innovation activity of the regions. The level of innovation development of a region is a key factor for growth of its competitiveness, for which reason it is of paramount importance to identify precisely and use correctly the tools for assessment of the innovation development economic efficiency of the region. The purpose of this article is to provide the grounds for the innovating capital indicator of a region and to adopt it as an innovation development efficiency indicator.

The tasks are to carry out a comparative analysis of the indicators for assessing the innovation development economic efficiency of a region by taking stock of global and domestic experiences, to clarify the concept of a region's innovating capital, to determine the structure of the innovating capital of a region, to identify the place (locus) of the innovating capital within the regional capital.

In the present conditions the innovation component in the activities of an enterprise, a region, and a country is gaining momentum. According to T. Schultz and G. Becker [1] "the new economy" is the economy of intangible factors of production such as human capital, intellectual property, and innovation activities. The principle of "national innovation capacity" becomes an incentive for development [2]. Nowadays socio-economic systems face a serious challenge of economic competitiveness failing to achieve the innovation imperative [3] and leading to emergence of the concept of "innovation deficiency" (at an enterprise, in a region and a country). For this problem to be solved a discrete policy related to innovations is being developed. Scientists draw the conclusion that if previously innovations were considered as an ascertaining analytical entity, now they are treated as a "framing component", a diagnostic lens or an analytical eyeglass though which one can observe or research the economic development of an enterprise, a region or a country [3-5]. That is why it is so important to search and find new tools and criteria of the innovation development of an enterprise, a region, and a country. With all the importance of innovation, unfortunately, there is no generally accepted, universally acknowledged and objective toolkit for assessing the economic efficiency of the innovation development of a region.

The research on innovation management used to be focused on an individual enterprise, now the innovation development of a region is taking on particular significance. The assessment of a region's innovation development is necessary to identify the scope and efficacy of the innovation policies implemented, to determine the leaders of innovation development and take stock of their best practices. Besides, it is important to specify the success factors and problems of innovation development for the purpose of justification of subsidies and providing support for the leading regions.

The current systems of innovation development assessment of the Russian regions are not always able to assess actual progress as well as shortcomings of the innovation activities because the set of scores for overall indexes is insufficient to provide an objective assessment. Besides, it appears difficult 
to form an overall index and to interpret it clearly. Some indexes and their meanings are insufficiently substantiated; there is no dynamic differentiation of weighting factors of different groups of indicators [6]. In order to achieve expected rapid progress in terms of innovations it is necessary to implement digital methods for collection and processing of data, mathematical modelling of industrial and economic processes, scientific experiments and improvement of analysis and assessment tools, including the indicator of innovating capital. On the basis of the domestic and international experience gained it is essential to create a new system of indicators of innovation development of a region capable of an objective assessment of actual results. In addition, the system of indicators has not only to be extended but fundamentally reviewed.

\section{METHODS AND MATERIALS}

This study was conducted based on the theory of management of a region's economy, the innovation management theory, the concept of sustainable development, the scientific foundations of strategic management, the theories of assessment and analysis of an enterprise's value, the value analysis, the methods of statistical monitoring and analysis, the methods, techniques and tools for regional economy management, the methodology and toolkit for performance assessment set out in the academic works by prominent Russian and foreign scientists.

\section{RESULTS}

It is found out that the majority of indicators of efficacy of a region's innovation development prevent from assessing the achieved level and, consequently, from identifying areas for development. A region's innovating capital indicator is proposed for use as an indicator of efficacy of a region's innovation development. The meaning of the indicator is clarified and the structure of innovating capital (human, intellectual, digital, patent capitals) and its locus in the regional capital (as an independent component and a part in all components of the regional capital) are determined.

\section{DISCUSSION}

The concept of "innovation development" in the scientific literature is interpreted as a qualitative change in the process of economic activity, based on the permanent search for new products, goods, new technologies that expand the market opportunities of an enterprise on the basis of various innovations [7-8].

Foreign experience in assessing the innovation development of a region. Currently, particular attention is paid abroad to the substantiation of the economic efficacy of scientific and innovation programs [9-14]. The financial resources are known and limited requiring an attentive and partial analysis of any innovation project. In international practice, extensive experience has been accumulated in the formation and use of indicators of innovation development of countries and regions, since it is the level of innovation development of a region that determines its competitiveness, which is especially significant in the context of globalization. Generally, two main approaches are in use, namely: the subjective approach (study of the innovation activities of enterprises in general: strategy, programs, problems, incentives) and the objective one (study of specific innovations: research and development). Besides, capital costs (all types of fixed assets, intangible assets) and current costs of innovations (usually wages) are studied. On the basis of quantitative assessments, the qualitative analysis is also carried out (in terms of regularity and consistency of innovation activities). To assess the innovation development of a region, the objective approach is usually used [5].

Since 2002, a two-level system of measuring innovation development has been used in Europe at the level of EU countries (EIS) (29 indicators) and at the level of EU regions (RIS) (16 indicators). The number of indicators of innovation development of a region is lower than that of a country due to the inaccessibility of certain data for statistics [6, 15-19]. The structure of indicators is identical, including innovation enablers, firm activities and innovation output. Based on the measured indicators, five types of innovation areas are formed. In order to measure the innovation development of regions (states) in the USA, an overall index (Portfolio Innovation Index) is used, consisting of four components of 5 to 7 indicators, namely: human capital, economic dynamics, productivity and employment, and welfare (with different weighting factors). Besides, one should take into consideration the systems of indicators used in different countries for assessing the innovation development of individual economic entities (enterprises). In the USA, for example, the STAR METRICS system is used to assess the efficiency of state research and innovation programs, which is based on the quantitative indicators of certain information databases, usually, reporting data [20]. The UK uses the REF (Research Excellence Framework) [21] system for assessing the efficiency of research and innovation programs implemented at universities, which is based on expert assessments. Both of the described methods for assessing the efficiency of innovation activities are interesting, but quite time-consuming in terms of collecting information and forming an array of data, the composition of indicators is questionable as well.

Russian experience in assessing the innovation development of a region. In Russia, the Innovative Russia 2020 strategic document defines the need to develop regional strategies of innovation development or sections on innovations within the framework of socio-economic development strategies of the constituent entities of the Russian Federation [22-25]. The innovation development outcomes are supposed to be assessed by known statistical indicators [25]. The level of innovation activity of the Russian regions is assessed by the innovation development index of regions. Similarly to the American system, it is based on three sets of indicators (the region's potential in creating innovations, the region's potential in commercializing innovations, the effectiveness of innovation policy in the region), to which certain weight coefficients are assigned. An indicator of the share of innovative products in the gross regional product, which ranges from 10 to $20 \%$ in the Russian regions, is acknowledged as one of the essential indicators of innovation activity in the regions. However, in our opinion, this indicator in absolute terms cannot characterize innovation 
activity in a region as the principle of comparability (the classics of analysis) is violated. The indicator is compared and evaluated for regions with different natural resources, different geographical locations (opportunities for innovation). This indicator's dynamics can characterize the activity of innovation activity to a certain extent, but only under certain conditions of assessment. The indicator of innovation costs (for instance, technological) points to the implementation of research and development of new products and new production processes (the indicator for Russian regions has a considerable differentiation as well). This indicator can be used to assess the efficacy of innovation development by comparing costs with the volume of innovative products but only on one's own initiative as long as the system does not suggest a comparison of these indicators.

Some scientific works provide their own system of indicators for the innovation development efficacy of a region (qualifying the level of innovation development of a region, the research potential of a region, the level of development of high-tech industries in a region or the position of a region in ratings) [26]. In the list of indicators there are those characterizing patent activity; the indicator used includes not just the volume of innovative products, but products for export (compliance with international requirements). Efficiency indicators are also used (implying the correlation of output and costs), in particular, the quantity to the cost of licensing contracts authorizing the use of intellectual property and the ratio of export and import of technologies and technological services [26]. However, the list of indicators other than those listed above does not differ essentially from the known statistical indicators for assessing innovation development.

Any process of activity is characterized by its output and costs (or resources used). Unfortunately, performance indicators are mainly represented by either GDP (for a country) or GRP (for a region) and indicators of the rate of some changes (absolute values, for instance, the number of enterprises engaged in innovation activities, or relative values, for instance, the share of innovative products in the total volume). Innovation costs are measured (usually research works and applied research) and monitored. However, none of the systems suggests a comparison of the output and costs (resources), which is the classics of efficiency assessment [27]. In only one of the research works [28] providing its own criteria and indicators for assessing the efficacy of innovation activities, it is supposed to evaluate the efficacy traditionally, that is, by the ratio of the output (Gross Regional Product) and innovation costs.

In a number of scientific works, the innovation development of regions is assessed by the results of clustering, formation and activities of innovation clusters. A clustering process itself, certainly, testifies to the innovation development of a region - on the terms of unification, coordination, and elaboration of common development programs for various business entities located in a certain area. The positive results of the clustering experience testify to this. However, there are also problems with the performance indicators of clusters, the most important of which consists in the coordination of the economic interests of a cluster's members and, accordingly, the problem of choosing performance indicators [29-32].

At the same time, the vague and unclear process of assessing the outputs of innovation activities gives rise to a significant regional differentiation and, as a result, problems with investment attractiveness and the formation of innovative infrastructure. The author [6] points out that public administration should focus on investing in technologically advanced fixed capital, activating the process of capital accumulation, thus, it is the first time that an approach in terms of capital appreciation appears

Innovating capital of a region. The use of the "capital" indicator (cost creation) as an efficacy indicator, which is referred to as the "cost approach" is not new (let us recall the balanced scorecard by D. Norton and R. Kaplan). It is essential that it is the capital indicator (an applied aspect) that acts as an integral indicator of performance meaning that the assessment of the capital or the cost implies accounting for outputs and expenses. A positive result of development should be acknowledged in case of "capital increment" (implementing the process of cost increase).

The concept of innovating capital of a region cannot be found in scientific literature; some publications have the innovating capital of an enterprise under review. Let us try, based on the results of the conducted research on cost management and efficacy assessment of innovation activities, to define the concept of "innovating capital of a region" and determine its structure.

The concept of innovating capital was mentioned for the first time within intellectual capital in the works of Joia L.A (2000) and Van Buren M. E. (1999); the works differentiated human, innovation, process and client capital. Innovating capital was treated as the total of everything forming intellectual property (intangible identifiable and unidentifiable assets)

The definition dictionaries interpret the concept of "innovating capital" as capital used to finance innovation projects, taking part in the turnover of innovative organizations and enabling industries and enterprises to manufacture high-tech products that meet international standards [33]. The formation of the capital structure of an organization (an enterprise) is known (for instance, fixed, working capital). Only some scientific papers mention "innovating capital". In [34-36], innovating capital is understood as the monetary value of all the innovation projects that are under development or already representing intellectual property. However, in this case, innovating capital is viewed only as the value (the procedure for market value assessment is carried out) of a number of specific innovation projects, both in the process of their development (which is quite complicated) and already fixed by official documents. According to another point of view, innovating capital is the value advanced into specific innovative resources (knowledge and competencies, business qualities and specific people) that contribute to the development or acquisition of innovations [2]. This definition is more specific, but the assessment procedure will a priori be more complicated. 
In other scientific works, innovating capital is considered as one of the elements of the intellectual capital of an organization (human, organizational, process, cultural capital and innovating capital), as one of the components of the intrinsic value of an enterprise [35-36]. Some authors define human capital as a constituent element of intellectual capital including also relationship capital (consumer, client, brand, and market) and structural (organizational) capital [37-40]. Other research works [41-43] compare intellectual capital (human capital, organizational capital, consumer capital client capital) and innovating potential (interaction, competence, resources, corporate culture). Sometimes intellectual (organizational capital), human capital, social and reputational capital [34] is distinguished. In the reviewed works devoted to the analysis and assessment of intellectual capital, innovating capital is given a secondary, auxiliary role. At the same time, it is people who create innovating capital by their active involvement in the elaboration and implementation of innovations, by their participation, labor, knowledge, skills, competencies, intelligence.

In our opinion, the innovating capital of a region is the value advanced into certain innovation-oriented resources of the region, which allow for the development and implementation of innovations. Consequently, the main goal of creating, maintaining and increasing the innovating capital of a region is to satisfy the region's needs for the sources of innovation development. The meaning of the concept of "innovating capital of a region" allows us to determine the principles of the formation of innovating capital of a region such as the inclusion of the development prospects of the region and economic entities of the area; the need to achieve a balanced development of all components of the innovating capital, the efficient use of the innovating capital; rationalization of costs for and digitalization (digital support) of the formation and maintenance of the innovating capital.

The structure of innovating capital of a region. The structure of a region's innovating capital, in our opinion, should be ([2], the content expanded): human capital of the region (labor resources involved in the innovation process, education and knowledge, individual professional skills, qualifications, professional competences, personal, psychophysiological abilities, forming competencies, i.e. individual and collective human capital) [44-45]; intellectual capital of the region (unidentifiable intellectual abilities of employees participating in the innovation process, their knowledge and skills, intellectual abilities, intellectual, creative and forming competences) [46-47]; patent capital of the region (identifiable items of intellectual property both created in the region and "acquired": ownership and use [48]). All used components of innovating capital can generate profit, and accordingly, its value can be estimated using cost assessment methods. Besides, given total digitalization, it is necessary to talk about digital capital. There is no generally accepted concept of digital capital yet. The definition of digital capital includes the possibility of developing methods for analyzing large amounts of data, approaches to processing data flow, creation of special information systems, use of various digital services. Digitalization places special demands on human capital; digital literacy is becoming the core competency [49-
51]. Thus, in our opinion, the digital capital of a region is the value advanced into certain innovation-oriented resources of the region that allow developing and implementing innovations, such as human capital of the region (digital component: digital literacy, mobility, flexibility), intellectual capital of the region (digital component: cognition, multifunctionality, creativity); patent capital of the region (digital component: skills and abilities to digitally formalize the results of scientific research and implementation of innovations - digital support).

Locus of innovating capital. Having proposed the structure of innovating capital, let us assume the "location" of innovating capital in the "genetic matrix of the regional economic system" [52-54]. Evolutionary economics, or gene economics, is likely to have passed its peak of popularity. However, the innovating capital of a region as a concept (content, principles of formation), as a certain structure (ratio of parts) should be part of regional capital, that is why we can talk about the locus of innovating capital. The authors of [55] suggested considering the region as a locus of innovating activity, i.e. the concentration of research and development on the territory of a particular region (a kind of "geo-tagging") since the innovating activity of any enterprise is based on the so-called local resources (natural resources, labor market, suppliers, consumers, intangible assets of areas, educational institutions). Mentioning local resources implies the presence and necessity to evaluate such a specific form of capital as innovating capital. In genetics, the term "locus" means the location of a particular gene (a region of a chromosome determining the development of one or more traits of an organism on a genetic or cytological map of a chromosome or inside a DNA segment of a molecule carrying genetic information). In our opinion, based on the above-mentioned definition of a locus from genetics and the principles of gene economics [52-54], innovating capital has to be considered as a certain locus of regional (territorial) capital. Regional capital should include material (natural resources of an area, fixed, working capital of economic entities), human capital and intangible assets (competences, knowledge, skills of residents, workers of an area). Innovating capital has to take its definite place in regional capital. Only by combining both tangible, intangible, and human resources, we can talk about the presence and increase of innovating capital. In its turn, the indicator of region's innovating capital (as an integral indicator), its presence, change, and increase can testify the efficiency of the innovation development of the region. Surely, the process of innovation "penetrates", connects all the components of regional capital. To assess innovating capital, it is necessary to take into account the human, intellectual, digital capital involved in the innovation process.

As can be seen from the above, the assessment of efficacy of the innovation development of a region in today's conditions requires new, correct, objective indicators of assessment (one can only manage what can be assessed). According to the comparative analysis of the domestic and foreign experience in assessing the efficacy of innovation development in a region, some generalizing indicators (indexes) are used universally, based on a number of "particular indicators of innovating activity". However, most 
of those particular indicators (statistically measured and observed in all countries) are essentially not efficacy indicators (there is no comparison, accounting for outputs and costs). We suggest using the indicator of innovating capital as an indicator of economic efficiency of the innovation development of a region. We have clarified its concept, determined the structure and locus in the regional capital.

\section{CONCLUSION}

1. We have carried out a comparative analysis of domestic and foreign experience in assessing the innovation development of a region and revealed that almost all of them are based on statistical indicators which are not efficacy indicators in essence.

2. We have clarified the concept of "innovating capital of a region" meaning the value advanced to certain innovationoriented resources of the region, allowing for development and implementation of innovations.

3. The structure of a region's innovating capital has been determined to include human, intellectual, digital capital taking part in the innovation process, and patent capital.

4. We have identified the place of a region's innovating capital within the regional capital: we have pointed out that innovating capital can be distinguished as an independent indicator of a region's innovation development and interconnected with all components of the regional capital.

We have designed the way forward for our further scientific research as the development of methodological support for assessing innovating capital and the creation of an analytical platform of indicators for monitoring and managing innovating capital of a region.

\section{References}

[1] M. Blaug, G.S. Becker, Great Economists since Keynes, Translated from English under the editorship of M.A. Storchevoi, St. Petersburg: Econ. Shool; Omega-L, 2009, pp. 29-32.

[2] S.V. Makusheva, "Innovating Capital in System of Corporations", Sci. Rev., no. 5, pp. 456-464, 2011.

[3] B.D. Matrizayev, "Formation of a New Model of Innovation Growth or the "Invisible" Logic of the Modern Innovation Imperative", Innovat. Econ. Issues, vol. 9, no. 1, pp. 111-136, 2019.

[4] M.R. Astapenko, I.A. Gorbacheva, T.P. Oslopova, D.A. Shpilev, A.V. Kovalenko, Socio-Economic and Financial Aspects of Innovation Development of Russian Economy, Monograph, Under the gen. ed. E.F. Nikitskaya, Yaroslavl: Avers Plus, 2013, 180 p.

[5] E.B. Lenchuk (ed.), Prospects for Innovative Development of Russian Regions. Moscow: Instit. of Econ. of Russ. Acad. of Sci., 2012, 324 p. ISBN 978-5-9940-0355-8

[6] A.A. Olovyannikov, Basic Theoretical and Methodological Approaches to Essence and Assessment of Innovation Development of a Region, vol. 06, no. 48, pp. 204-208, 2016, Retrieved from: https://cyberleninka.ru/journal/n/problemy-sovremennoy-nauki-iobrazovaniya (Reference date 11.12.2019).

[7] V.R. Zverev, G.A. Untura, V.I. Fedoseev, Innovation Activity, Terms of Innovation Management and Related Fields (from A to Z), Definition Dictionary, Execut. Ed. V.I. Suslov, Rus. Acad. of sci.. Siber. Branch, Institute of Economics and Industrial Engineering. Novosibirsk: Instit. of Econ. and Industr. Engineer., Siber. Branch of the Russ. Acad. of Sci., 2010, 269 p.

[8] U.A. Arutyunov, A.P. Sharanin, "Innovation Development as an Economic Category”, Creat. Econ., vol. 5, no. 2, pp. 8-12, 2011.
[9] A. Frenkel et al., "Demand-Driven Innovation: An integrative systemsbased review of the literature", Int. J. of Innovat. and Technol. Manag. vol. 12, iss. 2, pp. 1-31, 2015.

[10] S.O. Park, "Regional innovation strategies in the knowledge-based economy", Geojournal, vol. 53, iss. 1, pp. 29-38, 2001

[11] S.N. Odai, The role of science, technology and innovative industries in national development", Key determinants of national development: historical perspectives and implications for developing economies, 2015 , pp. 215-230, Retrieved from: https://www.routledge.com/KeyDeterminants-of-National-Development-Histori-cal-Perspectives-andImplications/Appiah-Adu-Bawumia/p/book/9781472462831 (reference date 17.12.2019)

[12] S. Marjanovic, S. Hanney, S. Wooding, A historical reflection on research evaluation studies, their recurrent themes and challenges, Santa Monica: RAND Corporation, 2009, Retrieved from: https://www.rand. org/pubs/technical_reports/TR789.html. Reference date 28.12.2019).

[13] S. Guthrie, W. Wamae, S. Diepeveen, S. Wooding, J. Grant, Measuring research. A guide to research evaluation frameworks and tools, Santa Monica: RAND Corporation, 2013. Retrieved from: https://www.rand. org/pubs/monographs/MG1217.html (reference date 28.12.2019).

[14] Evaluating outcomes of publicly-funded research, technology and development programs: Recommendations for improving current practice. American Evaluation Association, 2015. Retrieved from: https://www.rand.org/pubs/research_reports/RR266.html(reference date 20.12.2019).

[15] P.A. Balland, R. Boschma, K. Frenken, "Proximity and Innovation: From Statics to Dynamics", Regional Studies, vol. 49, no. 6, SI, pp. 907-920, 2015.

[16] A. Rodriguez-Pose, M. Di Cataldo, "Quality of government and innovative performance in the regions of Europe", J. of econ. geogr. vol. 15, no. 4, pp. 673-706, 2015.

[17] J. Edler, J. Fagerberg, "Innovation policy: what, why, and how", Oxford rev. of econ. policy, vol. 33, no. 1, pp. 2-23, 2017.

[18] F. Moulaert, F. Sekia, "Territorial innovation models: A critical survey", Regional studies, vol. 37, no. 3, pp. 289-302, 2003.

[19] M. Fritsch, V. Slavtchev, "Determinants of the Efficiency of Regional Innovation Systems", Regional studies, vol. 45, no. 7, SI, pp. 905-918.

[20] M. Largent, J. Lane, "STAR METRICS and the science of science policy”, Rev. of Policy Res., vol. 29, no. 3, pp. 431-438, 2012.

[21] Research Excellence Frame work. Retrieved from: http://www.ref.ac.uk

[22] N. Mikheeva, R. Semenova, Innovative Potential of Regions: Problems and Measurement Results, In The New Economics. Innovative portrait of Russia, Moscow: Center for Strategic Partnership, 2011, Retrieved from: http://komitet2-8.km.duma.gov.ru/file. $\quad x p ? i d b=2216676 \& f n=$ IPR4-Book.pdf\&size=28509852 (reference date: 18.12 .2019 ).

[23] A.M. Nosonov, "Features of Innovation Development of Russian Regions", Regionology, vol. 4, no. 89, pp. 22-31, 2014, Retrieved from: https://regionsar.ru/ru/ node/1318 (reference date: 15.02.2018).

[24] N.A. Skvortsova, O.A. Lebedeva, E.A. Sotnikova, "Innovation Development of Regions in Economic Space", Fundamental Res., no. 2, pp. 1265-1268, 2015, Retrieved from: http://fundamental-research.ru/ ru/article/view?id=37017 (reference date: 15.09 .2019 ).

[25] Official website of the Federal State Statistics Service (Rosstat) Retrieved from: https://www.gks.ru//(reference date 12.09.2019).

[26] I.E. Ilyina, E.N. Zharova, E.V. Agamirova, A.P. Kamensky "Innovation Development of Russian Regions", Regionology, vol. 26, no. 2, pp. 230-255, 2018, Retrieved from: https://regionsar.ru/ru/node/1679 (reference date: 15.10.2019).

[27] T.A. Nikitskaya, M.P. Astapenko, Assessment of Efficacy of Innovation Development Management in Regions, Retrieved from: http://uecs.ru/marketing/item/3828-2015-11-26-12-44-41 (reference date: 15.12 .2019$)$

[28] E.V. Erokhina, Methodology of Analysis and Assessment of Efficacy of Innovation in a Region, no. 4-1, pp. 3-17, 2013, Retrieved from: https://cyberleninka.ru/journal/n/izvestiya-tulskogo-gosudarstvennogouniversiteta-ekonomicheskie-i-yuridicheskie-nauki?i=1052540 (reference date: 15.12.2019). 
[29] V.V. Lizunov, "The Role of Clusters in Strategic Planning, Innovation Development and Regional Competitiveness", National Priorities of Russia, vol. 3, no. 17, pp. 97-108, 2015, Retrieved from: http://rusnatprior.ru/ pages/317-2015-god (reference date: 11.12.2019).

[30] D. Yoon, "The regional-innovation cluster policy for R\&D efficiency and the creative economy: With focus on Daedeok Innopolis", J. of Sci. and Technol. Policy Manag., vol. 8, iss. 2, pp. 206-226, 2017.

[31] J. Tsertseil, K. Ordov, "Cluster's innovaton development through the territory of the regions", European Proceedings of Social and Behavioural Sciences, vol. 10, pp. 50-57, May 2016 [3rd Int. conf. on political science, international relations and sociology, 425 p., 2016].

[32] G.P. Merzlikina, L.A. Plotitsyna, N.O. Mogharbel, "Innovation Industrial Clusters: Development Priorities", Econ. and Entrepreneurship, vol. 13, no. 8 (109), pp. 515-521, 2019.

[33] C. Grimpe, U. Kaiser, W. Sofka, "Signaling valuable human capital: Advocacy group work experience and its effect on employee pay in innovative firms", Strategic Manag. J., vol. 40, no. 4, pp. 685-710, 2019, Retrieved from: https://www.scopus.com/inward/record. uri?eid=2-s2.0-85055249786\&doi $=10.1002 \% 2 \mathrm{fsmj} .2957 \&$ partnerID $=40 \&$ md5=d5efa69e769e1eaa5f95e1014c5c2d3f (Reference date 12.12.2019).

[34] M.K. Akhtyamov, E.A. Gonchar, N.V. Tikhonova, "Assessment of Intellectual Capital of an Organization as an Element of Intrinsic Value of Enterprise", Creative Econ., vol. 10, no. 8, pp. 945-960, 2016.

[35] M.K. Akhtyamov, E.A. Gonchar, "Intellectual Capital in System of Valuation of a Company", Econ. and Entrepreneurship, no. 8-1, pp. 522-527, 2015.

[36] M.A. Palienko, "Innovation Capital as Way to Increase Labor Productivity", Problems of Improving the Organization of Production and Management of Industrial Enterprises, Interuniver. Coll. of Sci. Papers, no. 2, pp. 161-168, p. 163, 2014.

[37] A. Nagendra, M. Deshpande, "Human Resource Information Systems (HRIS) in HR planning and development in mid to large sized organizations", Procedia Social and Behavioral Sciences, vol. 133, pp. 61-67, Febrary 2013 [Int. Conf. on trade, markets and suitability (ICTMS-2013), 381 p., 2013].

[38] R.V.D. Jordao, J.C. Novas, "Knowledge management and intellectual capital in networks of small- and medium-sized enterprises", J. of intellectual capital, vol. 18, no. 3, SI, pp. 667-692, 2017.

[39] Z.K. Chulanova, A.A. Satybaldin, A.K. Koshanov, "Methodology for assessing the state of human capital in the context of innovative development of the economy: A three-level approach", J. of Asian Finance, Econ. and Busin., vol. 6, no. 1, pp. 321-328, 2019, Retrieved from: https://www. scopus. com/inward/record (Reference date 17.12.2020).

[40] T.E. Danilovskikh, A.G. Avakyan, "Human Capital Assessment Techniques", Approaches and Classifications in Fundamental Research, no. 6-1, pp. 108-111, 2015, Retrieved from: http://fundamentalresearch.ru/ru/article/view?id=38403 (reference date: 01.12.2019).

[41] H. Hussinki, P. Ritala, M. Vanhala, A. Kianto, "Intellectual capital, knowledge management practices and firm performance", J. of intellectual capital, vol. 18, no. 4, pp. 904-922, 2017.

[42] J. Volna, L. Kohnova, M. Bohdalova, M. Holienka, "Innovative Mindset and Management Styles: An Intellectual Capital Approach", Intellectual
Capital Knowledge Management \& Organizational Learning, October, pp. 316-323, 2015 [12th Int. Conf. on Intellectual Capital knowledge management and organization leaning ICIC, 485 p., 2015].

[43] K.V. Sayapina, O.E. Ustinova, "The Role of Intellectual Capital in Forming Innovation Potential of a Russian Organization", Creative Econ., vol. 13, no. 4, pp. 743-760, 2019.

[44] E.I. Pozolotina, "Methodology of Formation of Competency Model for a Large Enterprise”, Manager, vol. 9, no. 6, pp. 68-77, 2018.

[45] O. Tohochynskyi, O. Oliinyk, V. Anishchenko, O. Rembach O. Sheremeta, "Innovative approach to the assessment of the company's intellectual capital", Acad. of Strategic Manag. J., vol. 18, no. 2, p. 7, 2019, Retrieved from: https://www.scopus.com/inward/record.uri?eid=2s2.0-85066994333\&partnerID=40\&md5=1ffaa1a775ab33cff626b45bf25f28b1 (Reference date 3.12.2019).

[46] N. Abu Hasan, N.L. Abdullah, "Relationship between intellectual capital and innovative capabilities: Evidence from Malaysian SMEs", Int. J. of Busin. and Manag. Sci., vol. 8, no. 2, pp. 439-460, 2018, Retrieved from: https://www.scopus.com/inward/record.uri?eid=2-s2.085061971535 \&partnerID=40\&md5=b08521a26ca12367a81877959bc6c9b9 (Reference date 11.12.2019).

[47] V. Ndou, G. Secundo, J. Dumay, E. Gjevori, "Understanding intellectual capital disclosure in online media Big Data: An exploratory case study in a university", Meditari Accountancy Res., vol. 26, no. 3, pp. 499-530, 2018, Retrieved from: https:// www.scopus. com/inward/ record uri?eid=2-s2.085062600462\&doi=10.1108\%fMEDAR-03-20180302\& partnerID=40\&md5=160643d46d2e3483d3066263fb101146) (Reference date 14.12.2019).

[48] P.A. Nekrasov, "Economic Development through Prism of Patent Activity Dynamics", Probl. of Forecast., no. 2, pp. 113-120, 2019.

[49] V.K. Krutikov, E.V. Geraeva, "Digital Capital and Innovation Entrepreneurial Activity", Econ. and Entrepreneurship, no. 3, pp. 703-709, 2018.

[50] V.K. Krutikov, Digital Economy: Challenges and Opportunities, Kaluga: Publ. house of AKF Politop, 2018, 180 p.

[51] R.A. Dyatlov, "Network Human Capital of Millennials as a Driver of Digital Economy Development", no. 4, pp. 26-31, 2019, Retrieved from: https://roscongress.org/materials/izvestiya-sankt-peterburgskogogosudarstvennogo-ekonomicheskogo-universiteta-4-spetsialnyy-vypuskpo/ (Reference date 17.11.2019).

[52] O.V. Inshakov, "Economic Genetics as Basis of Evolutionary Economics", no. 10, pp. 6-16, 2006, Retrieved from: https:// cyberleninka.ru/journal/n/vestnik-volgogradskogo-gosudarstvennogouniversiteta-seriya-3-ekonomika-ekologiya?i=1047882 Reference date 25.12.2019).

[53] E.M. Martishin, G.K. Dzhunusheva, O.E. Martishin, E.P. Guskov, "The Foundations of Economic Genetics”, J. Sci. Idea of the Caucasus, no. 1, pp. 5-14, 2006.

[54] R.A. Boschma, "Competitiveness of regions from an evolutionary perspective”, Regional studies, vol. 38, no. 9, pp. 1001-1014, 2004.

[55] R.M. Vasin, L.A. Hamidullaeva, "Region as a Locus of Innovation", Theoret. and Appl. Econ., no. 2, pp. 1, 11, 2018, Retrieved from: https://nbpublish.com/library_read_article.php?id=20644 (reference date $5.01 .2020)$ 